\title{
Conservation banking mechanisms and the economization of nature: An institutional analysis
}

\author{
Valérie Boisvert* \\ Institute of Geography and Sustainability, Faculty of Geosciences and the Environment, University of Lausanne, Bat. Geopolis, Bureau 3522, CH-1015 \\ Lausanne, Switzerland
}

\section{A R T I C L E I N F O}

\section{Article history:}

Received 18 June 2014

Received in revised form

2 February 2015

Accepted 22 February 2015

\section{Keywords:}

Market-based instruments

Biodiversity offsets

Commodification

Land sparing

Institutional analysis

\begin{abstract}
A B S T R A C T
During the last decade, conservation banking mechanisms have emerged in the environmental discourse as new market instruments to promote biodiversity conservation. Compensation was already provided for in environmental law in many countries, as the last step of the mitigation hierarchy. The institutional arrangements developed in this context have been redefined and reshaped as market-based instruments (MBIs). As such, they are discursively disentangled from the complex legal-economic nexus they are part of. Monetary transactions are given prominence and tend to be presented as stand alone agreements, whereas they take place in the context of prescriptive regulations. The pro-market narrative featuring conservation banking systems as market-like arrangements as well as their denunciation as instances of nature commodification tend to obscure their actual characteristics.

The purpose of this paper is to describe the latter, adopting an explicitly analytical stance on these complex institutional arrangements and their performative dimensions. Beyond the discourse supporting them and notwithstanding the diversity of national policies and regulatory frameworks for compensation, the constitutive force of these mechanisms probably lies in their ability to redefine control, power and the distribution of costs and in their impacts in terms of land use rather than in their efficiency.
\end{abstract}

(c) 2015 Elsevier B.V. All rights reserved.

\section{Introduction}

During the last decade, conservation banking mechanisms have emerged at least in the environmental discourse as allegedly new market instruments to promote biodiversity conservation (Madsen et al., 2010, 2011). However compensation was already provided for in environmental law in many countries, as the last step of the mitigation hierarchy. Since mitigation measures were most of the time accomplished on site and in kind, they were considered as technical components of development projects rather than as a policy instrument. Compensatory mitigation was conducted on a project-byproject basis, under the control of the authorities in charge of wildlife and protected areas without global scheme and away from public exposure.

New representations and expectations have been progressively attached to this policy, following the changes in wetland mitigation policy in the United States during the 1990s (Robertson, 2000, 2004, 2006) and the setting of the no-net-loss objective. With this slogan promoted by the Bush Administration, full offsetting of the projected ecological loss associated with wetland destruction became the explicit goal of mitigation policies. The mitigation banking mechanism

\footnotetext{
*Tel.: +41 216924429.

E-mail address: valerie.boisvert@unil.ch
}

was developed to provide compensation for adverse impacts to wetlands and other aquatic resources in advance of the impact. Wetlands were to some extent commoditized through a process that has been described by Robertson (2000) as an "incomplete capitalization of nature". Narratives of market, science, and technique have played an important role in this institutional innovation. The development of market-style flexibility mechanisms in mitigation policies has been explicitly linked to expectations associated with restoration science and practice. As stressed in "expectations studies" recently developed in the field of social studies of science, technology and society (STS) (Borup et al., 2006; Brown et al., 2000, Brown, 2003), expectations act as constitutive forces, they create promissory commitment that become part of a shared agenda and thus require action. In this case, the promise of no net loss (NNL) - i.e. the theoretical possibility of conciliation between economic development and environmental protection without trade-offs or compromises thanks to ecological restoration techniques (Brownlie et al., 2013) - has been central in brokering relationships between actors. NNL goal stands for an optimum policy that would ensure a perfect balance between the maintenance of natural capital - an environmental status quo, without further degradation - and economic growth, through the implementation of land development projects and the expansion of an expertise sector - brokers, consultants - dedicated to mitigation. The promissory abstraction of ecological equivalence has taken substance and has become materially embedded into specific institutional arrangements 
that have been called "mitigation banks". The vocabulary used to describe these mechanisms - banks, bankers, credits, debits, etc. - and the associated legal framework are eloquent testimony to the underlying neoliberal vision. Mitigation banking is described as a marketbased instrument (MBI), and as such is expected rather than demonstrated to be efficient, transparent, to favour the development of routines, to foster long-term conservation at ecologically sound scales, and to reduce transaction costs.

Conservation banking emerged in the United States in the mid1990 s as an attempt to adapt wetland mitigation banking framework to the protection of endangered species. In 1995, the State of California established the first conservation banks, to preserve existing habitats. At the Federal level, the U.S. Fish and Wildlife Service (2003) adopted a "Guidance for the establishment, use, and operation of conservation banks", hereafter the Guidance, in May 2003. Similar programmes have been adopted from the end of the 1990s worldwide (Australia, Brazil, South Africa, Europe). Beyond their diversity, the arguments used to promote them draw upon similar representations and discourses about market efficiency and the promises of ecological restoration.

Mitigation banking and conservation banking schemes are sometimes jointly addressed under the heading of habitat banking (Bean et al., 2008), especially in literature-based surveys or theorizing about MBIs. 'No net loss' and even 'net gain' or 'net positive impact' are often discussed in relation to conservation banking as if the compliance regimes for biodiversity offsets always had such explicit objectives (BBOP 2012, 2013; Bull et al., 2013; Coggan et al., 2013). This conflation between different policy instruments and institutional arrangements is misleading. It is indisputable that conservation banking has been inspired by mitigation banking, yet it would be delusive to consider them as identical. They fall within the scope of different legislative instruments and policy frameworks, their objectives are materially different, the agencies in charge of the implementation of the policy are not the same and they have different intervention cultures and representations of the environment. As set out below, it is therefore improper to apply without due discrimination to conservation banking the results and conclusions drawn from the analysis of mitigation banking systems.

Conservation banking schemes have been redefined and reshaped as MBIs from the mid 1990s. As such, they are discursively disentangled from the complex legal-economic nexus they are part of. Monetary transactions are given prominence and tend to be presented as stand alone agreements whereas they take place in the context of prescriptive regulations and broad-ranging conventions, leading to what Brand and Vadrot (2013) call 'epistemic selectivities'. ${ }^{1}$ Conservation banking systems are entrenched into regulatory frameworks that give them meaning and that should not be disregarded. The pro-market narrative featuring them as market-like arrangements as well as their denunciation as instances of nature commodification tend to obscure their actual characteristics. The purpose of this paper is to describe the latter, adopting an explicitly analytical stance on these complex institutional arrangements and questioning their economic status.

Conservation banking systems are very diverse, and even within a country, the principles laid down in regulations are actualized through varied institutional arrangements. The aim of this paper is not to draw up an inventory or a typology of these arrangements, but rather to identify their common institutional features beyond their diversity, based on an analysis of the legal framework governing them, building on Polanyi's concept of 'fictitious commodities' and on the literature on the neoliberalization of nature in radical geography (e.g. Harvey, 2007; Castree, 2003, 2010a, 2010b).

${ }^{1}$ Brand and Vadrot (2013): 207 define epistemic selectivities as "those mechanisms within political institutions that favour specific forms of knowledge, problem perceptions and narratives over others."
The first part of this paper will be devoted to a critical appraisal of the notions of MBIs and markets as used in designing environmental policy instrumentation. Several key features or criteria defining MBIs will be defined and the major steps of the commodification process leading to market creation will be identified. These elements will direct an assessment of the conservation banking sector. This part will be followed by a discussion of the economic status of the institutional arrangements into which ideal expectations of markets and ecological equivalence are materially scripted.

\section{Commodification, markets and market-based instruments: The nature of the markets for nature}

Whereas many environmental policy tools are categorized as market-based instruments, this notion is paradoxically ill defined from an analytical point of view. This category is not reflected in a substantive definition. The characterization of mechanisms as MBIs arises from projected qualities and expectations - efficiency in resource allocation and an explicit reliance on market regulation rather than from their objective attributes. These instruments are described as "harnessing market forces" (Hockenstein et al., 1997). Some authors consider in addition that they would fall within price rather than quantity regulation. As defined by Hockenstein et al. (1997): 14, "Market-based instruments are regulatory devices that shape behaviors through price signals rather than explicit instructions on pollution control levels of measure". However, this proposal for a definition does not withstand scrutiny: tradable permits, including credit programs and cap-and-trade systems, that are always identified as MBIs in typologies of policy instruments are a form of quantity regulation. In fact, this category is most of the time addressed through a negative definition, and opposed to "command-and-control" approaches, which are equated to pure regulation conjuring up visions of inefficiency, administrative burden, and rigidity. In setting uniform technical standards, "command-and-control" instruments would force all firms to shoulder identical share of the mitigation burden, regardless of their differences in terms of cost structure and technology and would therefore provide little incentive to spare resources.

The concept of MBI was initially articulated and brought to the fore in relation to environmental policies by Stavins $(1988,1991)$ in a report to the U.S. Congress entitled Project 88, and he has further developed it ever since (e.g., Stavins, 1998). The category of MBIs as defined by Stavins includes various instruments that are all featured as economic incentives: tradable permits, charge systems (e.g., effluent charges, deposit-refund systems, user charges, sales taxes), market friction reductions (i.e. market creation, liability rules and information programmes), and government subsidy reductions (removal of perverse incentives). This is a broad categorization; some of these elements can hardly be described as 'instruments'. The development of environmental liability has its own rationale going beyond market framing. These so-called instruments do not make a coherent whole from a theoretical point of view. Nor do they convey a shared vision of environmental externalities.

Until the inception of the concept of MBIs and its breakthrough in relation to the provision and management of ecosystem services, environmental policy instruments were split into two broad groups according to their theoretical foundations (OECD, 1989). The major divide was between Pigouvian taxes - implying the intervention of the State or of a regulatory body to internalize externalities - and the economic instruments, also called market incentives and associated with a Coasian setting-tradable permits, and various contractual instruments. In surveys of environmental policies and their theoretical background (e.g., Cropper and Oates, 1992) the imposition of legal liability for damages to the environment was also considered, and the authors pointed to the practical importance of the locus of environmental regulatory authority. This partitioning and the underlying 
references are still structuring the periodical surveys of environmental policy instruments edited by the OECD.

Defining an environmental policy instrument as a MBI does not say much about its intrinsic characteristics and properties. It rather reveals the cost-efficiency expectations attached to its adoption, and potentially a subscription to the liberal market ideal. Pleading for MBIs' development is therefore vague as a policy prescription and cannot provide precise criteria against which institutional change, the resulting arrangements, and their performance could be assessed. In this respect, the concept of MBIs is similar to the concept of market in economics.

\subsection{Setting up markets for biodiversity: The steps towards commodification}

The conceptualization of market is the core of economic theory; it represents the ideal type and the reference in terms of efficiency in resource allocation. Yet the economic theory is not very explicit about the terms and conditions of its actualization and its practical implementation. Unless if taking a cue from Hayek one considers that markets arise spontaneously, their creation implies institutional framing, the identification of actors, the delineation of commodities, and the setting up of trading devices. Real-life markets are not pure abstractions, and they are deeply enmeshed in social, cultural, political and legal processes and materially embedded into structures. These dimensions are studied in economic sociology. In this field, 'market devices' defined as "a simple way of referring to the material and discursive assemblages that intervene in the construction of markets" (Muniesa et al., 2007: 2) are one of the main subjects of study. Market creation implies the definition of the commodity to be traded and of the property rights of the parties involved. It requires the setting up of institutional arrangements effectively matching supply and demand. Regardless of the institutional configuration of the market, economic agents are assumed to be free to allocate their resources as they wish, and to engage in transactions or not. Their involvement in commercial exchange is voluntary. Finally, however the market is conceptualized, it is characterized by a price, determined by the law of supply and demand at a global level and independent from the contingencies of individual transactions, especially from the material setting in which they take place and the personal and social relationships among the actors involved.

As has been highlighted in the literature on the commodification of nature (e.g., Castree, 2003, 2010a, 2010b; Gómez-Baggethun and Ruiz-Pérez, 2011), the environmental markets differ from conventional markets in that they deal with 'fictitious commodities' in the Polanyian sense, disembedded from wider social and ecological relations to be turned into tradable assets (Polanyi, 1944). Their (re)definition as commodities bears witness to capitalist expansion and to the creation of new resource frontiers through a process of 'accumulation by dispossession' to quote Harvey (2003). The commodification of elements of biodiversity involves a series of operations (adapted from Castree, 2003):

- Individuation of the prospective assets, implying the creation of conceptual and material boundaries, and the splitting of ecosystem into legally defined and tradable entities that are most of the time property rights to specific resources or services:

- Reification resulting in the alienability of the biodiversity elements, in their being materially and culturally separable from the ecosystems and from their owners if any, who are defined in the process as potential sellers;

- Abstraction, which aims at setting individual things as equivalent, or 'making things the same' to quote McKenzie (2009), describing how different gases had been made commensurable and how accountants had struggled to define a standard treatment of emissions rights in preparation for carbon markets. Turning social facts and elements of biodiversity into 'things' necessitates to set up 'conventions of equivalence' (Desrosières, 1998; Espeland and Stevens, 1998), i.e. to produce statistics, averages, standard deviations, correlations, probability, identical categories. The production of types depends on inventories, lists, classification, and standardization of natural habitats. Abstraction also implies to disentangle the elements of biodiversity from the ecosystems and the particular location or site they are embedded in. These elements are at least conceptually isolated from the socioecological dynamics they are involved in.

- Measurement, quantification, search for metrics and currencies, i.e. the definition of fungible units of trade. This issue and step of the social construction of species or habitats as assets is closely related to the previous one and proves especially challenging in the case of biodiversity and ecosystem services, as illustrated by Salzman and Ruhl (2000). A classification of these elements should be defined so as to allow commensurability and substitution among the entities belonging to the same category regardless of their location, but the ecological and social values of biodiversity are site specific and changing.

\subsection{Commodification, capitalization or economization?}

As already mentioned, Robertson (2000) described the development of mitigation banking as a process of incomplete capitalization of nature. In the case of conservation banking, the process is not only unfinished, it is more fundamentally difficult to define and label. The conservation banking mechanisms that have developed throughout the world are all based on the sale and purchase of very specific credits. The assessment procedures are not standardized and are highly context dependent, as discussed below, resulting in each transaction being unique. There is no market, properly speaking, for biodiversity or species credits since there is no generalized and centralized system for the exchange of homogeneous credits, and the deal flow is too limited to build up mutual trust, to share information, and to settle transactions into a routine.

With this in mind, we could hazard a new definition of MBIs, as instances of uncompleted processes of nature commodification, or to put the question another way focusing on their performative dimensions, as instances of economization of nature. As defined by Çalişkan and Callon (2009): 370 economization is "a term used to denote the processes that constitute the behaviours, organizations, institutions and, more generally, the objects in a particular society which are tentatively and often controversially qualified, by scholars and/or lay people, as 'economic'. The construction of action (-ization) into the word implies that the economy is an achievement rather than a starting point or a pre-existing reality that can simply be revealed and acted upon."

The economic status of conservation banking devices cannot be fully understood without an outline of the economization process at stake in the development of this policy instrument. A major analytical challenge to address lies in the identification of the traded entity. In other terms, it should be determined what these transactions mean, what the credits stand for, and what precisely gives rise to payments. Can the amount paid to purchase credits be regarded as a price? Is it rather an ex-post compensation, or a form of regularisation? Is habitat destruction authorized once compensatory mitigation measures have successfully been implemented or is the permit issued against the credible promise of appropriate habitat restoration or preservation? How are uncertainties about future impacts and the success of restoration dealt with in quantifying debits and credits? Another important aspect of the definition of the economic status of conservation banking mechanisms relates to property rights. Indeed, the 
property rights over commodities must be well defined for trade to be possible. According to the theory of property rights, all trade can be considered as an exchange of property rights. The institutional arrangements governing conservation banking should be described in all their complexity: by unfolding the rights and correlative obligations of the land developers and bank managers but also by unveiling the bundle of relationships and transactions in which they are enshrined. Some of these transactions are monetary; others are regulatory rather than economic. Some agreements are finalized before the exchange of credits, other afterwards. Many different actors engage in these transactions: various public authorities, land developers, bank managers, landowners, brokers, legal and environmental consultants, ecological restoration specialists. The description of the bundle of agreements among them can reveal to what extent the purchase of credits in a conservation banking system can be considered as a voluntary transaction.

These questions cannot be addressed only theoretically. They should be considered in actual institutional settings through case studies, because as acknowledged in the introduction of the Guidance "no two conservation banks will be used or developed in an identical fashion." The following sections give an overview of issues and sketch out some potential directions for a future research agenda.

\section{Conservation banking through a market lens}

Numerous articles and publications have recently focused on the short - history of conservation banking in the United States, from the emergence of wetland mitigation banking through the transfer of the concept to threatened species conservation with the beginning of conservation banking in California during the mid-1990s (e.g., Bauer et al., 2004; Bean et al., 2008; Carroll et al., 2008). Otherwise a great deal of research has been devoted to the Endangered Species Act (ESA) of 1973 and its implementation, especially in the field of law and economics, in relation to property issues (e.g., Houck, 1993, 1995; Innes, 1997; Thomson, 1997; Polasky et al., 1997). Experiences from different countries in terms of biodiversity, species or habitat banking have also been reviewed (e.g., Burgin, 2008; McKenney and Kiesecker, 2009).

Conservation banking has first developed and been studied in the United States, but the socio-political paths followed by other countries that have developed domestic versions of this instrument are more or less similar. Until the mid-1990s, compensatory measures were a technical step in a compulsory mitigation procedure. Their implementation was negotiated locally on a project-by-project basis and depended on local contingencies. There was often a bargain over the compensatory measures prescribed by the environmental authorities, the outcome of which depended among others on the particular development project at stake, the technical capacity and the financial health of the land developer. It would be excessive to describe them as token measures, however they were often defined on the basis of a rule of thumb rather than of a scientific estimation of predictable habitat losses and the application of a ratio to account for possible restoration failures. Compensatory mitigation measures were decided and implemented along with the development projects or after them, without prior global scheme or land planning. The representations and hence the practice - of biodiversity offsets have evolved following the liberal shift of the 1980s, the gradual dissemination of market instruments in the field of conservation policies and the popularization of the 'no-net-loss of wetlands' slogan during the Presidential campaign of George H.W. Bush in 1988 (Robertson, 2004). The principle of proportionality between compensatory mitigation measures and residual environmental damages has been asserted in this context, leading to the notion of ecological equivalence.

However in most countries, this change in perspective and the evolution of the functions assigned to offsetting mechanisms have taken place in an unaltered legal framework. The take ${ }^{2}$ of endangered or threatened species is considered as exceptional in nature, it is subject to authorization and the land developer must follow the mitigation hierarchy: offsetting measures are the last resort solution to address residual environmental impacts of land development projects after appropriate avoidance, minimization and restoration measures have been applied. Biodiversity loss can to some extent be compensated for through the preservation or restoration of a habitat that is considered as equivalent to the affected one in terms of conservation benefits to the listed species. Until recently compensatory mitigation measures were often implemented by the land developers themselves or by specialized service providers they mandated. Conservation banks offer an additional possibility for permittees to comply with their regulatory obligations. The demand for credits depends on the number of permits issued by the authorities upstream in the process. The voluntary nature of the transaction is thus limited and debatable from the point of view of the permittees: they are lawfully obliged to carry out mitigation measures, but free to choose among several options to perform this obligation. Furthermore, the obligation to offset residual damages caused to biodiversity is not transferred to the conservation bank through the purchase of credit. It is a personal obligation. The purchase of credits cannot be strictly speaking considered as a transfer of property rights, it merely enhances the flexibility of regulatory compliance.

\subsection{The U.S. experience of conservation banking}

As already mentioned, in the United States, the ESA makes it unlawful to 'take' a listed species. In 1982, the ESA was amended to authorize incidental taking of endangered species by private landowners and other non-federal entities provided they developed habitat conservation plans (HCP) minimizing and mitigating the taking and that received approval by the U.S. Fish and Wildlife Service or the National Marine Fisheries Service pursuant to §7. Conservation banking was first promulgated in the State of California in 1995. From the mid1990s, the Fish and Wildlife Service (FWS) has allowed credits from conservation banks to be used to meet the requirements of the ESA. Federal Guidance has been adopted in 2003 but it is quite informal, especially compared to the Federal wetland compensatory mitigation policy framework. The guidance is meant as a "collaborative incentivebased approach to endangered species conservation" rather than as a legally binding one (U.S. Fish and Wildlife Service, 2003; Bauer et al., 2004) and it leaves room for interpretation and adaptation.

Conservation banks are established, used and operated within the boundaries of the ESA. Their working is shaped and constrained by definitions, categories, priorities, zoning, that are not questioned in the context of the exchange of conservation credits. Endangered and threatened species are listed at State and Federal levels, and an administrative procedure is launched if a land development project may result in an 'incidental taking'. The land developer must provide an ecological impact assessment of the project, estimate the potential biodiversity loss and habitat destruction that might be induced by the project and propose measures to mitigate or compensate these damages in a Habitat Conservation Plan. The latter is assessed by the FWS that decides to deliver - or not - a permit and prescribes compensatory mitigation measures that can include the nature and number of credits that the developer should purchase.

In parallel, in anticipation of future mitigation requirements, landowners invest in conservation activities at a site, which is called a bank. These activities are not precisely defined, they may include the acquisition of high quality habitat, or the restoration of a degraded habitat for one or several particular species, buffering of protected

\footnotetext{
2 'Take' is defined by the ESA as "harass, harm, pursue, hunt, shoot, wound, kill, trap, capture, or collect, or to attempt to engage in any such conduct."
} 
areas or connecting separated habitats. The bank project must be assessed and approved by the FWS. State and local government entities may impose additional environmental requirements. The bankers must set up a 'conservation banking agreement' indicating a management plan for the bank property, a description of the service area, the number and kind of conservation credits within the bank and the performance standards that it should meet (Bauer et al., 2004). Credits are awarded for conservation outcomes-e.g. enhanced or created habitats, number of nesting pairs; their issuance is therefore conditional on the success of the management plan. Most importantly, the conservation commitment made by landowners when they establish a bank is permanent. They must convey a permanent conservation easement over the bank property and provide assurance of long-term funding for the perpetual management of the property.

The ecological suitability of the site is one of the main criteria considered in assessing the eligibility of a bank project. The banks should be capable of either supporting a viable population of an endangered species or contributing to the maintenance of the species population by expanding an existing protected area managed for this species. Public agencies are allowed to establish banks; it is a common practice of state and local transportation departments for instance, but most banks are privately owned and managed. The prospective bankers often get into the conservation business because it is their only option to develop their lands that host endangered species, which it is illegal to harm. In a way, they try to make the best of a bad hand (Carroll et al., 2008). As acknowledged by the Guidance (U.S. Fish and Wildlife Service (2003): 1), "from the landowner's perspective, it provides a benefit, an opportunity to generate income from what may have been previously considered a liability." Establishing a bank can also be a means to prevent the partition of a family heritage because the conservation commitment made when establishing a bank is permanent (Bauer et al., 2004). Landowners' interests and access to land are decisive in the choice of locations for conservation banks. In this context, the environmental authorities cannot have a complete control over the siting of the banks, but they strive to impose an ecologically coherent global scheme. They perceive conservation banking as a means to reinforce and secure centralized control of conservation policies. The expectations attached to these emerging institutional arrangements are not defined in terms of market, efficiency, flexibility, or private property. Nor are these mechanisms referred to as autonomous transactions. They are part of a land planning approach to conservation. In the Guidance, when describing the expected effects of conservation banking, greater emphasis is placed on consistency, predictability, and the need to plan and articulate private decentralized initiatives, than on the alleged efficiency of the latter (U.S. Fish and Wildlife Service, 2003).

The declared purpose of conservation banking is not to ensure 'no net loss' or ecological equivalence. As stated in the Guidance (U.S. Fish and Wildlife Service, 2003), "while in mitigation banking the goal is to replace the exact function and values of the specific wetland habitats that will be adversely affected by a proposed project, in conservation banking the goal is to offset adverse impacts to a species. [...] In contrast to mitigation banks, an appropriate function of conservation banks is the preservation of existing habitat with long-term conservation value to mitigate loss of other isolated and fragmented habitat that has no long-term value to the species". The location of the banks and their management plans are not dictated by the imperative of full compensation, they are guided by listed species conservation needs, based on conservation biology principles. The establishment of conservation banks and the ensuing credit sales are not isolated independent transactions with their own rationale; they form part of an overall coherent ecological scheme. As a result, a wide range of projects are eligible as conservation banks. The Guidance provides that "a bank can be created in a number of different ways: (1) acquisition of existing habitat; (2) protection of existing habitat through conservation easements; (3) restoration or enhancements of disturbed habitat;
(4) creation of new habitat in some situations; and (5) prescriptive management of habitats for specified biological characteristics."

In practice, the U.S. Fish and Wildlife Service tends to favour preservation strategies over restoration, enhancement or creation of habitats (Mead, 2008). Unless habitat maintenance requires active management (e.g. control of invasive species, controlled burning, grazing), mitigating damages to endangered species using preserved habitats - rather than restoring degraded ones - could result in a net loss of suitable habitat for a particular species. ${ }^{3}$

It is therefore difficult to determine what the credits precisely stand for; they are certainly not just a medium in an exchange of equivalents, since there is no guarantee whatsoever that the habitats destroyed and the habitats protected or recreated are equivalent. In purchasing credits, land developers pay for the cost of compliance. The transaction per se rather than the number of credits actually exchanged is relevant in this respect.

The economization process at stake in conservation banking can be assessed based on this outline of the U.S. system and on the above description of the operations leading to turn ecosystem parcels into commodities-individuation, reification, abstraction and measurement.

\subsection{An incomplete commodification process?}

Beyond discourses, conservation banking mechanisms even though fast expanding and highly publicized are still of minor practical import in conservation policies, compared to more conventional conservation tools. They may feature high in symbolic and rhetorical terms, but they have not aroused a groundswell of support even in United States. There are conservation banks only in a limited number of states, concerning a limited number of endangered or threatened species and types of habitats. Some of them even enjoy a de facto monopoly position. The information on conservation banking is not centralized, while in contrast an information system called RIBITS (Regulatory In Lieu Fee and Bank Information Tracking System) has been implemented for mitigation banking. Each transaction is therefore highly dependent on the particular setting within which it takes place and the species considered. While the object of the transactions is not completely different from one contract to the next, it is not the same either, and a sequence of transactions is not sufficient to support integration or consolidation that could lead to a market.

As already mentioned, there is a distinct type of credit for each species and each habitat type and for each of them different ecological assessment methods can be used. According to a study commissioned by the USDA Office of Environmental Markets, more than 40 distinct methods representing four main types of metrics are applied to the assessment of habitats (Willamette Partnership, 2011). ${ }^{4}$ Based on a literature survey of biodiversity offsetting schemes worldwide, Quétier and Lavorel (2011) identify, compare and consider the merits and scope of validity of three main approaches to assess ecological equivalence. ${ }^{5}$ These methodological reviews bespeak the lack of common approach to habitat assessments. Thus, even if the explicit objective of conservation banking were to achieve ecological equivalence, the currency issue would be quite sensitive. It is all the more complex since the federal legislation leaves room for interpretation and adaptation. There is no established doctrine, and

\footnotetext{
${ }^{3}$ Indeed, the credits issued by preservation banks are granted by the Service against the committment of the bank managers to maintain existing habitats in perpetuity. They do not involve net creation or protection of habitats, whereas they can be bought to satisfy legal requirements, as compensation for habitat loss elsewhere.

${ }^{4}$ This report identifies vegetation-based, species-based, functions-based, and practice-based metrics (Willamette Partnership, 2011).

5 These approaches are labelled 'circumstancial reasoning', 'standardized scoring method', and 'standardized scoring method and like-for-similar correspondence' (Quétier and Lavorel, 2011).
} 
ultimately the onus is on the Service personnel to decide whether particular conservation measures are proportionate. In practice, each ecological assessment process is unique. Conservation banks can rely on a range of strategies that all contribute towards the protection or recovery of listed species, but may widely differ in terms of their environmental impacts: preservation, management, restoration of degraded habitats, buffering of already protected areas, or creation of habitat (U.S. Fish and Wildlife Service, 2003). The credits issued in these different contexts cover many different ecological realities.

In addition, the number of credits allocated to a bank project and the number of credits to purchase to offset the detrimental impacts of a land development project form the subject of distinct assessments, carried out at different times, potentially with different hypotheses and techniques, and possibly by using different indicators, ratio, discounting and probability rating. It is eventually difficult to make sure that the supply and the demand of credits actually have the same meaning.

Beyond the specific case of the U.S. conservation banking system, the notion of credits as biodiversity currencies is therefore problematical. As stated by Walker et al. (2009): 151, simple biodiversity currencies are inadequate; they facilitate nominal biodiversity accounting, but omit, obscure, or conceal biodiversity features and noninterchangeabilities. No general equivalent, no yardstick or standard has emerged from experience to date and ecologists insist that this currency issue is probably intractable.

The lack of fungibility of the credits reflects an incomplete process of abstraction. The 'investments in form' to develop typologies, commensurability and define homogenous categories have not been pushed to their conclusion. Habitats and biodiversity assets generally speaking are situated, they cannot be separated from their context, the social, cultural and environmental values attached to them in their original location, and their evolutionary path (Brownlie et al., 2013). Each transaction is thus unique and embedded in a particular context from which it cannot be abstracted.

The institutional arrangements set up to ensure offsetting - e.g., the agency approval of the bank, the conversion of the conservation value of the bank into a fixed number of credits by the FWS stem from local dynamics, bargains, and subjective assessment of the seriousness, reliability and professionalism of the would-be bankers. The outcome of transactions on credits depends on the relationship established between the parties. It cannot be completely objectified and regarded as the sole product of the inherent characteristics of what is being traded. As summarized by Walker et al. (2009): 151 quoting Salzman and Ruhl (2000): 614, "Incomplete measurement, imprecise valuation, and noninterchangeability mean biodiversity exchange is strictly not commodity trading, but barter: "individuals haggling over goods and services with unique attributes"." There is no such thing as a price for credits, rather something like bargaining mediated by money.

Accordingly, the sale of species or habitat credits relate to biodiversity but do not involve biodiversity elements as such, rather loosely defined rights over habitats. These rights cannot be depicted as property rights: the purchase of credits does not involve any transfer of formal rights. Offsetting requirements are a matter of personal obligation that cannot be transferred.

Finally, though often presented as an isolated contract between conservation bankers and land developers to fit the Coasian model of bilateral negotiation, the exchange of credits is part of a far more complex institutional setting. The ecological impact assessments, the ecological restoration activities, the various legal agreements, conventions and covenants and the trust fund that provides assurance of long-term funding for the conservation banks involve recourse to various forms of technical expertise that neither landowners nor land developers do have. For these issues they rely on various brokers, consultancies, and lawyers, who support them in preparing and drawing up mandatory documents and contracts and assist them in their dealing with authorities at the local, state and federal levels. The organization of conservation banking is therefore very far from the economic ideal of a direct supply-demand encounter. Beyond the differences across countries, all the biodiversity banking systems take place within a permit system, they are organized through bundles of contracts, agreements and binding planning documents, involving many stakeholders over the long term. The analysis of conservation banking should adopt a holistic approach to this institutional constellation and not be confined to the sole purchase of habitat or species credits by land developers.

Given these distinctive features, the conservation banking schemes can hardly be termed "biodiversity markets". The enlistment of the private sector in conservation policies can be considered an omen of neoliberalization of nature. However the participation is so tightly regulated and framed by law that it does reveal the domination of an entrepreneurial form of nature management typical of neoliberal governmentality, ${ }^{6}$ rather than an actual commodification of nature, even incomplete.

\section{On the impact of presenting conservation banks as MBIs}

As already noted above, featuring conservation banking schemes as MBIs has performative effects. These schemes are not turned into markets just because they are considered as such, but mitigation policies are reshaped and redefined by the pro-market narrative. Some important aspects of the policy devices are ignored, some actors, interventions and processes are made invisible, strong assumptions are made about the working of the banks and their performances that are not sustained by evidence. Complex negotiations are presented as market-like exchange, and the land use decisions made in compensation policies are interpreted as rational choices inducing ecologically sound strategies. Monetary transactions are brought to the fore at the expense of the numerous other agreements, settlements, bargaining and arrangements that frame biodiversity offsetting. The purchase of credits in conservation banking systems is often presented as a stand-alone agreement, while it is entangled in a web of formal and informal rules and negotiations. The role of the regulatory framework though quite visible in real-life arrangements is not highlighted in many accounts of this mechanism, especially in economics. However public intervention is not limited to setting the scene, allocating property rights and creating a level playing field. Conservation banking entails a great degree of intervention to award credits, define obligations, and assess habitats. Fox and Nino-Murcia (2005) report that most of the bank owners they met in the context of their survey of conservation banks in United States complained about the bureaucratic burden implied by this activity. Moreover some banks are managed by public bodies, which goes largely unreported in the promotional discourse focusing on private initiative and individual interests as well as in criticism.

Whereas the very justification of compensatory mitigation is the need to offset impacts occurring elsewhere, conservation banks tend to be included in surveys of environmental policy instruments as tools for the conservation of biodiversity. The positive side of the offset is highlighted. The restoration of degraded habitats, the preservation and management of others to enhance the provision of ecosystem services, and the contribution of biodiversity offsets to species recovery are advertised. In contrast, the negative side associated with habitat destruction, which is its correlate, is comparatively less publicised. This can be illustrated by the example of Cossure natural assets reserve in France, established by CDC biodiversité, which is a private subsidiary of a parastatal organization. CDC biodiversity has acquired

\footnotetext{
${ }^{6}$ As defined by Foucault in his Lectures at the College de France in 1978
} (Foucault, 2004). 
land occupied by industrial orchards in the South of France, in the Cossouls de Crau that is a unique semi-arid steppe ecosystem, home to endangered bird species. The ecosystem was in a serious state of deterioration and its rehabilitation through the removal and recycling of irrigation pipes, ecological engineering, revegetation, and ecological management of the site based on eco-pastoralism has produced visible results (Chabran and Napoleone, 2012). This operation has been used to showcase conservation banking in France and has accordingly been presented in a very favourable light. ${ }^{7}$ However, the conservation actions carried out to compensate for impacts occurring elsewhere to the same resource, although presented as virtuous and cost-efficient can at best offset the depletion of biodiversity caused by other projects and result in a zero-sum game. Given the wide gap existing between the promises raised by the restoration science and its practical achievements (Maron et al., 2012), these strategies actually result in most cases in a net loss of endangered species habitat.

These systematic distortions and selectivity in the description of existing institutions to have them conform with an economistic worldview are reminiscent of Polanyi's concept of 'economistic fallacy', i.e. the assumption that all societies are founded on market-exchange oriented individual action and should be modelled accordingly. Values, economic rationality and market categories are projected onto institutions and natural environments without due consideration of their reality. The criticism of conservation banking as commodification of nature paradoxically reinforces its representation as market or MBI. However, the economization of endangered species and their habitats is not necessarily a prelude to their commodification. Measurement and quantification processes, typology setting and the definition of conventions of equivalence are already well underway, but their being part of a commodification project is not obvious.

The development of conservation banking more or less along the same lines as wetland mitigation banking is justified by a search for efficiency. These mechanisms are allegedly a flexible and costefficient means of meeting conservation requirements. From the Service's perspective, conservation banking reduces the piecemeal approach to conservation efforts that can result from individual projects by establishing larger reserves and enhancing habitat connectivity (U.S. Fish and Wildlife Service, 2003: 1). Conservation banking is therefore above all perceived as a streamlining strategy rooted in managerial legitimacy. This organization of biodiversity compensatory mitigation is praised for its technical performance and functionality: the partition between supply and demand of credits, and the spatial concentration of mitigation measures are expected to bring transparency and accountability and to facilitate monitoring and regulatory compliance. The ambitions or expectations attached to conservation banking are summarized by Mann and Ashber (2014): 74: On the one hand, these tradable permit systems promise to reduce costs, dampen the adversarial nature of regulation and support economic growth while still achieving regulatory and conservation goals. In addition, they are collaborative, enlisting market and civic actors in the design and delivery of such policies, calling for new forms of relationships between state and non-state actors in the process of policy formulation and implementation. The case for conservation banking is strengthened by supposedly compelling environmental arguments: scientifically sound conservation strategies would be easier to define and more likely to succeed in large unfragmented regions (Sullivan, 2013). This common sense argument, appealing for its simplicity is however specious, as discussed below. The choice of a land use strategy to ensure biodiversity protection depends on the conservation targets. Under the pretence of ecosystem protection, the same concern for managerial control is

${ }^{7}$ For instance in a video entitled "Métamorphose: naissance d'une réserve d'actifs naturels", 2011. reasserted. Conservation banking pertains to 'technologies of power' and its goals are defined in terms of discipline and control rather than mere commodification.

The way conservation banking mechanisms have been developed from the late 1990s and are put into perspective nowadays reflects most of all the fact that market rhetoric has become pervasive in environmental politics. The - mainly discursive - conversion of environmental policy tools into MBIs, involving their reshaping and reinterpretation to bring out their formal analogies with markets, has become an end in itself.

If conservation banking systems had to be compared with existing policy instruments, they could be interpreted as an adapted form of transferable development rights (TDR) (OECD, 1999: 84; 2004; Machemer and Kaplowitz, 2002). TDRs are generally employed to preserve historic heritage or the environment. They are used to guide growth and development by focusing land-use change into targeted geographic areas. TDR allows for the market transfer of development rights from landowners in areas designated for preservation to landowners and developers for use in areas deemed appropriate for development. TDRs involve therefore partial transfers of rights to use land that, in a biodiversity management context, restrict activities on ecologically sensitive private lands. These can include restrictions on development, by implementing legally binding property covenants or land management plans, both of which may be based on biodiversity management goals (OECD, 2004). Conservation banks and their service areas are in a way similar to the 'sending districts'. They can sell credits to developers who look for solutions to implement compulsory mitigation. These credits could be interpreted from the bankers' perspective as TDRs. Yet there are some differences between the systems: the emission of credits is the raison d'être of the conservation banks, not the unintended effect of restrictions due to land planning or real estate legislation; TDRs can be stored or transferred, which is not the case of species or habitat credits. However such a parallel illustrates that conservation banking policy, rather than an attempt at commodifying nature, is a land-sparing policy (Phalan et al., 2011), favouring spatial segregation and specialization. This land use approach supports the concentration of development activities on built-up and intensively cultivated lands, so that other areas can be set aside for conservation. This approach has not proven to be more efficient in terms of environmental protection than land sharing, but it has not been discarded either (DeFries et al., 2004; Fischer et al., 2011). However, if this model were disseminated in densely populated areas with limited land reserves, for instance in Europe, it would raise questions. Indeed it would probably give still higher priority to the establishment of preservation banks - in other words habitat maintenance - over restoration projects (for an account of the UK experience, see Hannis and Sullivan, 2012; Sullivan, 2013), with a risk to accentuate ecological inequalities and to cause an overall decline of vulnerable habitats. Indeed, conservation efforts and resources would be focused on already preserved areas, existing ecologically important habitats, while the promise of their protection in perpetuity guaranteed by the conservation easement would in return justify ecosystem conversion elsewhere.

\section{Conclusion}

Featuring conservation banking mechanisms as MBIs reveals the expectations of their promoters and the fears of their detractors rather than their objective characteristics. The exchange of credits always takes place in unique circumstances and setting. For localized transactions to evolve into a market, it would be necessary to centralize information, to homogenize credits and define currencies for biodiversity, to enhance the transparency of exchanges and to improve and standardize both habitat assessment methods and 
restoration techniques. As illustrated above, these preconditions are far from being fulfilled.

The exchange of species or habitat credits cannot be described as a voluntary transaction, at least not from the perspective of land developers. The latter are indeed responsible for undertaking appropriate offsetting measures but can choose how they will fulfil this obligation. On the supply side, most banks are privately owned and managed, but their activity is enshrined in regulations. The location of the bank, the management plan, the number of credits it can issue, and the agenda of credit release all depend on prior administrative authorisation. In addition, the demand of credits depends on the number of permits granted, hence on the level of legal compliance. In most banking systems presently in force, the credits cannot be hoarded.

Characterizing biodiversity banking schemes as markets or MBIs would imply the identification of the commodity traded. Habitat and species related credits have been described by critics as "licences to kill' specimens of endangered species or licences to destroy their habitats. However the permits are granted prior to the purchase of credits, which cannot be considered as a way to 'buy' authorisation. Given the complexity of the definition and measurement of ecological equivalence, and the imprecise eligibility criteria applying to mitigation measures, the credits cannot play the role of currency or general equivalent. They may contribute to making exchanges more fluid, while keeping up the appearance of market regulation, but they fundamentally pertain to a bartering logic.

In contrast to markets, there is no transfer of property rights under these institutional arrangements: the permittees have a personal obligation they cannot transfer to offset the residual damages caused by their projects.

Rather than nature commodification, the development of conservation banking probably reveals the domination of a managerial approach to environmental policies influenced by engineering. Restoration techniques, management practices and ecological engineering play a decisive role in this respect, as well as land use planning and the spatial concentration of the areas devoted to conservation. The delimitation of development areas and conservation banks, and the definition of distinct supply and demand for credit convey the notion of a partitioned geographic and social space, allowing the functional territorial specialization and the professionalization of the actors. The economization of species and habitats is intended to rationalize and reinforce the control over conservation policies and to improve the production of processed nature.

However, a market imaginary literally pervades conservation banking policies. The references to no net loss and ecological equivalence, even used metaphorically, can induce a normalization of habitat destruction and foster the illusion that a processed nature could be a surrogate for the lost one. Beyond offsetting methods, the simple fact of conceptualizing conservation along these lines reduces environmental policy to a balance sheet approach.

\section{Acknowledgements}

This research has been carried out within the framework of the INVALUABLE research project (European project funded by ERA net Biodiversa).

\section{References}

Bauer, M., Fox, J., Bean, M.J., 2004. Landowners bank on conservation: the U.S. Fish and Wildlife Service's guidance on conservation banking. Environ. Law Rep. 34, 10717-10722.

Bean, M., Kihslinger, R., Wilkinson, J., 2008. Design of US Habitat Banking Systems to Support the Conservation of Wildlife Habitat and at-risk Species. The Environmental Law Institute, Washington, DC.
Borup, M., Brown, N., Konrad, K., Van Lente, H., 2006. The sociology of expectations in science and technology. Technol. Anal. Strateg. Manage. 18 (3/4), 285-298.

Brand, U., Vadrot, A., 2013. Epistemic selectivities and the valorisation of nature: the cases of the Nagoya protocol and the intergovernmental science-policy platform for biodiversity and ecosystem services (IPBES) law. Environ. Dev. J. 9 (2), 202-220, Available at??/http://www.lead-journal.org/content/13202.pdf).

Brown, N., Michael, M., 2003. A sociology of expectations: retrospecting prospects and prospecting retrospects. Technol. Anal. Strategic Manage. 15 (1), 3-18.

Brown, N., Rappert, B., Webster, A. (Eds.), 2000. Contested Futures: A Sociology of Prospective Techno-Science. Ashgate Publishing Ltd., Aldershot, UK.

Brownlie, S., King, N., Treweek, J., 2013. Biodiversity tradeoffs and offsets in impact assessment and decision making: can we stop the loss? Impact Assess. Project Apprais. 31 (1), 24-33.

Bull, J.W., Suttle, K.B., Gordon, A., Singh, N., Milner Gulland, E.J., 2013. Biodiversity offsets in theory and practice. Oryx 47 (3), 369-380.

Burgin, S., 2008. Biobanking: an environmental scientist's view of the role of biodiversity banking offsets in conservation. Biodivers. Conserv. 17, 807-816.

Business and Biodiversity Offsets Programme (BBOP) 2012. Resource Paper: No Net Loss and Loss-Gain Calculations in Biodiversity Offsets, Washington, DC.

Business and and Biodiversity Offsets Programme (BBOP) 2013. To No Net Loss and Beyond: An Overview of the Business and Biodiversity Offsets Programme (BBOP), Washington, DC.

Caliskan, K., Callon, M., 2009. Economization, Part 1: Shifting attention from the economy towards processes of economization. Econ. Soc. 38 (3), 369-398.

Carroll, N., Fox, J., Bayon, R., 2008. Conservation and Biodiversity Banking: A Guide to Setting Up and Running Biodiversity Credit Trading Systems. Earthscan, London.

Castree, N., 2003. Commodifying what nature? Prog. Hum. Geogr. 27 (3), 273-297.

Castree, N., 2010a. Neoliberalism and the biophysical environment 1: What 'Neoliberalism' is, and what difference nature makes to it. Geogr. Compass 4 (12), 1725-1733.

Castree, N., 2010b. Neoliberalism and the biophysical environment 2: Theorising the neoliberalisation of nature. Geogr. Compass 4 (12), 1734-1746.

Chabran, F., Napoléone, C., 2012. Les conditions du développement des banques d'actifs naturels en France. Développement durable et territoires 3 (1), http: //dx.doi.org/10.4000/developpementdurable.9199.

Coggan, A., Buitelaar, E., Whitten, S., Bennett, J., 2013. Factors that influence transaction costs in development offsets: who bears what and why? Ecol. Econ. 88, 222-231.

Cropper, M., Oates, W., 1992. Environmental economics: a survey. J. Econ. Lit. 30 (2), 675-740.

DeFries, R.S., Foley, J.A., Asner, G.P., 2004. Land-use choices: balancing human needs and ecosystem function. Front. Ecol. Environ. 2 (5), 249-257.

Desrosières, A., 1998. The Politics of Large Numbers: A History of Statistical Reasoning. Harvard University Press, Cambridge, MA.

Espeland, W.N., Stevens, M.L., 1998. Commensuration as a social process. Annu. Rev. Sociol. 24, 313-343.

Fischer, J., Batáry, P. Bawa, K.S., Brussaard, L., Chappell, M.J., Clough, Y, Daily, G.C., Dorrough, J., Hartel, T., Jackson, L.E., Klein, A.M., Kremen, C., Kuemmerle, T. Lindenmayer, D.B., Mooney, H.A., Perfecto, I., Philpott, S.M., Tscharntke, T. Vandermeer, J., Wanger, T.C., Von Wehrden, H., 2011. Conservation: limits of land sparing. Science 334 (6056), 593.

Foucault, M., 2004. Sécurité, territoire, population. Cours au Collège de France (1977-78). Gallimard/Seuil, Paris.

Fox, J. Nino-Murcia, A. 2005. Status of species conservation banking in the United States. Conserv. Biol. 19, 996-1007.

Gómez-Baggethun, E., Ruiz-Pérez, M., 2011. Economic valuation and the commodification of ecosystem services. Prog. Phys. Geogr. 35 (5), 613-628.

Hannis, M., Sullivan, S. 2012. Offsetting Nature? Habitat Banking and Biodiversity Offsets in the English Land Use Planning System, Greenhouse, UK.

Harvey, D., 2003. The New Imperialism. Oxford University Press, Oxford.

Harvey, D., 2007. A Brief History of Neoliberalism. Oxford University Press, Oxford.

Hockenstein, J., Stavins, R., Whitehead, B., 1997. Creating the next generation of market-based environmental tools. Environment 39 (4), 13-20 30-33.

Houck, O.A., 1993. The endangered species act and its implementation by the U.S Departments of Interior and Commerce. Univ. Colo. Law Rev. 64, 277-370.

Houck, O.A., 1995. Why do we protect endangered species, and what does that say about whether restrictions on private property to protect them constitute 'takings'? Iowa Law Rev. 80, 297-332.

Innes, R., 1997. Takings, compensation and equal treatment for owners of developed and undeveloped property. J. Law Econ. 40, 403-432.

Machemer, P., Kaplowitz, M.D., 2002. A framework for evaluating transferable development rights programmes. J. Environ. Plann. Manage. 45, 773-795.

Madsen, B., Carroll, N., Moore Brands, K., 2010. State of Biodiversity Markets Report: Offset and Compensation Programs Worldwide. Forest Trends, Washington, DC.

Madsen, B., Carroll, N., Kandy, D., Bennett, G., 2011. Update: State of Biodiversity Markets. Forest Trends, Washington, DC.

Mann, C., Ashber, J., 2014. Adjusting policy to institutional cultural and biophysical context conditions: the case of conservation banking in California. Land Use Policy 36, 73-82.

Maron, M., Hobbs, R., Moilanen, A., Matthews, J., Christie, K., Gardner, T., Keith, D. Lindenmayer, D., McAlpine, C., 2012. Faustian bargains? Restoration realities in the context of biodiversity offset policies. Biol. Conserv. 155, 141-148.

McKenney, B., Kiesecker, J., 2009. Policy development for biodiversity offsets: a review of offset frameworks. Environ. Manage. 45, 165-176.

McKenzie, D., 2009. Making things the same: gases, emission rights and the politics of carbon markets. Acc., Organiz. Soc. 34, 440-455. 
Mead, D., 2008. History and theory: the origin and evolution of conservation banking. In: Carroll, N., Fox, J., J., Bayon, R. (Eds.), Conservation and Biodiversity Banking: A Guide to Setting Up and Running Biodiversity Credit Trading Systems. Earthscan, London, pp. 9-32.

Muniesa, F., Millo, Y., Callon, M., 2007. An introduction to market devices. Specia issue Sociological review monographe series, 'Market devices'. Sociol. Rev. 55 (s2), 1-12.

OECD, 1989. The Application of Economic Instruments for Environmental Protection. OECD, Paris.

OECD, 1999. Handbook of Incentive Measures for Biodiversity Design and Implementation. OECD, Paris.

OECD, 2004. Recommendations of the Council on The Use of Economic Instruments Inpromoting The Conservation and Sustainable Use of Biodiversity, OECD, Paris.

Phalan, B., Onial, M., Balmford, A., Green, R.E., 2011. Reconciling food production and biodiversity conservation: land sharing and land sparing compared. Science 333 (6047), 1289-1291.

Polanyi, K. 1944. The Great Transformation. The Political and Economic Origins of Our Time. Beacon Hill, Boston.

Polasky, S., Doremus, H., Rettig, B., 1997. Endangered species conservation on private land. Contemporary Econ. Policy 15, 66-76.

Quétier, F., Lavorel, S., 2011. Assessing ecological equivalence in biodiversity offset schemes: key issues and solutions. Biol. Conserv. 144 (2011), 2991-2999.

Robertson, M, 2000. No net loss: wetland restoration and the incomplete capitalization of nature. Antipode 32 (4), 463-493.

Robertson, M., 2004. The neoliberalization of ecosystem services: wetland mitigation banking and problems in environmental governance. Geoforum 35 (3) 361-373.

Robertson, M., 2006. The nature that capital can see: science, state, and market in the commodification of ecosystem services. Environ. Plann. D: Soc. Space 24 $367-387$.
Salzman, J., Ruhl, J.B., 2000. Currencies and the commodification of environmental law. Stanford Law Rev. 53, 607-693.

Stavins, R.N. (Ed.), 1988. Project 88: Harnessing Market Forces to Protect Our Environment, Sponsored by Senator Timothy E. Wirth, Colorado, and Senator John Heinz, Pennsylvania, Washington, DC.

Stavins, R.N. (Ed.), 1991. Project 88-Round II Incentives for Action: Designing Market-based Environmental Strategies, Sponsored by Senator Timothy E. Wirth, Colorado, and Senator John Heinz, Pennsylvania, Washington, DC.

Stavins, R. 1998. Market-based Environmental Policies. BCSIA Discussion Paper 9802, ENRP Discussion Paper E-98-02, Kennedy School of Government, Harvard University, February 1998.

Sullivan, S., 2013. After the green rush? Biodiversity offsets, uranium power and the 'calculus of casualties' in greening growth. Hum. Geogr. 6 (1), 80-101.

Thomson Jr., B., 1997. The endangered species act: a case study in takings and incentives. Stanford Law Rev. 49, 305-380.

U.S. Fish and Wildlife Service 2003. Guidance for the Establishment, Use, and Operation of Conservation Banks, May 2, 2003.

Walker, S., Brower, A., Stephens, T., Lee, W., 2009. Why bartering biodiversity fails. Conserv. Lett. 2, 149-157.

Willamette Partnership 2011. Measuring Up: Synchronizing Biodiversity Measurement Systems for Markets and Other Incentive Programs. A Report Funded by the U.S. Department of Agriculture, Office of Environmental Markets. 